\title{
EVALUATION OF SERUM HIGH-SENSITIVITY C-REACTIVE PROTEIN LEVELS DURING VARIOUS PERIODS OF PREGNANCY IN WOMAN, INFECTED WITH PARVOVIRUS - B19 INFECTION
}

\author{
Natalia Bondarenko \\ Department of obstetrics and gynaecology No. 1 \\ O. O. Bogomolets National Medical University \\ 13 Shevchenko blvd., Kyiv, Ukraine, 03150 \\ Perinatal center \\ 9 Predslavinskaya str., Kyiv, Ukraine, 03150 \\ nataliabondareno@gmail.com
}

\begin{abstract}
The aim of the research was analyze of C-reactive protein levels in serum blood samples during various periods of pregnancy in women, infected with parvovirus B19 and in case of presence of clinical complications.

129 pregnant women, infected with parvovirus B19 infection and 16 women with physiological pregnancy during first, second and third trimesters of pregnancy were examined. Depending on the presence or absence of clinical complications each group of pregnant women (I, II, III) was divided into two subgroups. The concentration of C-reactive protein in blood serum was determined by the method of immunoassay analysis using diagnostic sets of reagents (ELISA kits, USA). Statistical processing of data was carried out using the package of applied programs Microsoft Office Excel 2010 and StatSoft Statistica 6.1.

The mean age of pregnant woman in our study was $26 \pm 6$ years. In the Iand II groups of infected B19 parvovirus pregnant women were identified a significant increasing of C-reactive protein levels compared to controls by $62.5 \%$ and $50.0 \%$ ( $<<0.05$ ). The largest increasing of C-reactive protein level relative to control values was observed in women with clinical complications in different pregnancy periods $(\mathrm{p}<0.05)$.

An increase levels of the marker of systemic inflammation the C-reactive protein in the blood testifies to its active participation in the launch of a complex mechanism for the development of labor activity and the occurrence of fetal disorders, which was confirmed in groups of pregnant women with clinical complications in different periods of pregnancy.
\end{abstract}

Keywords: pregnancy, parvovirus B19 infection, C-reactive protein.

\section{Introduction}

Among the factors which have bad influence on pregnancy, virus infections are one of the most important. Fetal viral infection can cause fetal death, undeveloped pregnancy or miscarriage. Usually these pathologies are associated with acute respiratory viral infections, influenza, measles, parotitis, poliomyelitis, acute Coxsackie viral infection. Parvovirus infection in pregnancy - acute viral infection caused by parvovirus B19 (Primate erythro parvovirus) and characterized by a variety of clinical manifestations. Nowadays the role of systemic inflammatory process in the physiology andpathology of pregnancy becomes more important. Most of the inflammatory reactions are localized in the area of damage, particularly in tissues of the endo- and myometrium (that is a result of trophoblast invasion), but in some cases systematic inflammatory response can happen. C-protein is diagnostic marker, which indicates the presence of inflammatory processes in the body of pregnant women [1]. An increase of the CRP level above $8 \mathrm{mg} / \mathrm{L}$ indicates the risk of pregnancy loss. Systemic inflammatory response during physiological pregnancy is caused by genetic "foreignness" of fetus, but the reason of pathologic pregnancy is the decompensation of systems that regulate systemic inflammatory response [2]. Role of CRP is not only binding the components of microorganisms and toxins, but also binding of cytokines, IL-4, TGF $\beta$, which possess suppressive properties. Therefore, it could facilitate the switching of the immune response from humoral to cellular. When connected to any of the ligands, CPR acquires the ability to activate the complement (both in classical and alternate way). Also, CRP can bind to lymphoid cells, playing with phagocytes 
and platelets the role of an immune modulator. By activating the complement and all dependent reactions (adhesion, chemotaxis, phagocytosis) and modulating the activity of immunocompetent cells and platelets, the CRP carries out the connection between the various components of the inflammatory process. Therefore, the main role of CRP is recognising various substances presented on microorganism's cells or human tissues surfaces, activation of the corresponding functional systems and, consequently, elimination of pathogens, as well as "old" and necrotized cells of the body.Nowadays the role of systemic inflammatory process in the physiology andpathology of pregnancy becomes more important. System inflammatory response during a normal pregnancy occurs because of an effect of "extraneous body», which is a result of normal difference between mother and fetus genotypes. In case of decompensation of system controlling the inflammatory response may cause pathological course of pregnancy [3]. C-reactive protein (hs-CRP) is a blood test marker for inflammation in the body of pregnant women [4]. In most of cases inflammatory centers are located in places of damage of endo- and myometrium during trophoblast invasion $[5,6]$, but sometimes occurs general inflammation. During the normal pregnancy levels of hs-CRP can increase up to $3 \mathrm{mg} / \mathrm{l}$, if hs-CRP increases over $8 \mathrm{mg} / \mathrm{l}$ it enhances probability of premature delivery in two times. High levels of hs-CRP from 5 to 19 weeks of pregnancy can lead to spontaneous abortion [7, 8].

Increased hs-CRP levels during pregnancy are often associated with poor pregnancyoutcomes, such as preeclampsia [9, 10], fetal growth retardation syndrome andintrauterine infection [11]. Hs-CRP is one of the early components, which can protect from infection [12, 13]. Just 2-4 hours after invasion, the level of hs-CRP increases, that lead to stimulation ofimmune reactions, such as phagocytosis, induction of pro-inflammatory cytokines(IL-1, IL-6, TNF-a) [14], monocyte tissue factor and activation of classicalcomplement pathway. Therefore, hs-CRP is considered as the most sensitive andrapid indicator of tissue damage during inflammatory process and it helps to detecteven minimal inflammation, and make faster diagnostic process for using the optimal treatment strategy $[15,16]$.

Approximately $30 \%$ of pregnant women have no immunity to parvovirus B19infection. Frequency of infection during the pregnancy is near $0.4-3.7 \%$, and itmay cause spontaneous abortion (5-8\%) or intrauterine fetal infection leading tomal formations [17]. Pregnant women more often have asymptomatic course ofparvovirus infection (60\% of cases). Subclinical forms of parvovirus disease appear much more often than manifestation forms [18, 19]. Therefore, more often pregnant womenhave retrospective thoughts about acute parvovirus infection, when appears disordercommon for parvovirus B19 - "non-immune fetal hydrops" [20]. It is a reason, why hs-CRP test is needed for diagnostic of subclinical forms of parvovirus infectionbetween patients with premature delivery $[21,22]$, preterm labor or presence of clinicalcomplications.

\section{Aimof research}

To analyze of hs-CRP levels in serum blood samples during various periods ofpregnancy in women, infected with parvovirus B19 and in case of presence ofclinical complications.

\section{Materials and methods}

On the basis of the Perinatal Center of Kiev, pregnant women were tested for the presence of parvovirus infection in the 2012-2017period. 129 pregnant women, infected with parvovirus B19 infection (from 19 to 39years old, mean age $-26 \pm 6$ years) were examined in the research. Patients weredivided into three groups (groups I, II, III) depending of a period of gestation. Subgroups of pregnant women without clinical complications were named as Ia, IIa and IIIa. Subgroups with complications named as Ib, IIb and IIIb. 16 woman formed the control group with physiological course of pregnancy in different trimesters. The concentration of hs-CRP in blood serum was determined by the method of immunoassay analysis using diagnostic sets of reagents (ELISA kits, USA).

The statistical processing of the obtained results was carried out using standard methods of variation statistics, taking into account the differences in the Student $t$ criterion, which was 
estimated using the confidence probability (p) less than 0.05 using Microsoft Office Excel 2010 for Windows and StatSoftStatistica6.1. The results are described as $\mathrm{M} \pm \mathrm{m}$. [23].

\section{Results of research}

From 129 pregnant women with parvovirus infection 57 (44.2\%) of them had increased levels of hs-CRP (exceeding was $20 \%$ from control level in currenttrimester). Infected patients from I and II groups showed significant increasing of hs-CRP levels comparatively with woman from control group: $62.5 \%$ and $50.0 \%$,respectively (Table 1). Levels of hs-CRP of pregnant women from group III haddifference from the control group just on $29.8 \%(\mathrm{p}<0.05)$.

\section{Table 1}

Levels of hs-CRP in blood serum of pregnant B19-infected women in different trimesters

\begin{tabular}{ccccccc}
\hline $\begin{array}{c}\text { Trimester } \\
\text { groups }\end{array}$ & $\begin{array}{c}\text { Control group, } \\
\text { n }\end{array}$ & Healthy & Main Groups & n & Infected & $\mathbf{\Delta}, \%$ \\
\hline $\begin{array}{c}\text { I trimester } \\
(\mathrm{n}=50)\end{array}$ & 5 & $5.6 \pm 0.8$ & I & 45 & $9.1 \pm 1.4 *$ & +62.5 \\
$\begin{array}{c}\text { II trimester } \\
(\mathrm{n}=54)\end{array}$ & 6 & $65.4 \pm 0.5$ & II & 48 & $8.1 \pm 1.0^{*}$ & +50.0 \\
$\begin{array}{c}\text { III trimester } \\
(\mathrm{n}=36)\end{array}$ & 5 & $54.7 \pm 0.9$ & III & 36 & $6.1 \pm 1.0$ & +29.8
\end{tabular}

Note: ${ }^{*}-p<0.05$ compared to a group of healthy pregnant women; $\Delta$-difference compared with data from healthy pregnant women

Pregnant women from the main group according to the trimester of pregnancy were divided into subgroups: without clinical complications are grouped into Ia, IIa, IIIa subgroups and withclinical complications during pregnancy - in the Ib, IIb, and IIIb subgroups.

Comparing subgroups of pregnant infected women with or without complications showed significant increasing of hs-CRP in groups Ib, IIb, IIIb (Table 2).

\section{Table 2}

Levels of hs-CRP in blood serum of pregnant B19-infected women with (groups «b») or without (groups «a») clinical complications

\begin{tabular}{|c|c|c|c|c|c|c|}
\hline \multirow{2}{*}{$\begin{array}{l}\text { Trimester } \\
\text { groups }\end{array}$} & \multicolumn{6}{|c|}{ Level of hs-CRP, mg/l (n=145), $M \pm m$} \\
\hline & $\mathbf{n}$ & Healthy & Groups & $\mathbf{n}$ & Infected & $\Delta, \%$ \\
\hline $\begin{array}{l}\text { I trimester } \\
\quad(\mathrm{n}=50)\end{array}$ & 5 & $5.6 \pm 0.8$ & $\begin{array}{l}\mathrm{Ia} \\
\mathrm{Ib}\end{array}$ & $\begin{array}{c}6 \\
39\end{array}$ & $\begin{array}{c}7.21 .3 \\
9.41 .6 \pm^{*}\end{array}$ & $\begin{array}{l}+28.6 \\
+67.8\end{array}$ \\
\hline $\begin{array}{l}\text { II trimester } \\
\qquad(\mathrm{n}=54)\end{array}$ & 6 & $5.4 \pm 0.5$ & $\begin{array}{l}\text { IIa } \\
\text { IIb }\end{array}$ & $\begin{array}{l}19 \\
29\end{array}$ & $\begin{array}{c}6.7 \pm 1.2 \\
9.1 \pm 0.9^{*}\end{array}$ & $\begin{array}{l}+24.1 \\
+68.5\end{array}$ \\
\hline $\begin{array}{l}\text { III trimester } \\
\quad(\mathrm{n}=41)\end{array}$ & & $54.7 \pm 0.9$ & $\begin{array}{l}\text { IIIa } \\
\text { IIIb }\end{array}$ & $\begin{array}{c}30 \\
6\end{array}$ & $\begin{array}{c}5.8 \pm 1.2 \\
7.9 \pm 0.6^{*}\end{array}$ & $\begin{array}{l}+23.4 \\
+68.1\end{array}$ \\
\hline
\end{tabular}

Note: $*-p<0.05$ compared to a group of healthy pregnant women; $\Delta$-difference compared with data from healthy pregnant women

Levels of hs-CRP from all groups of B19-infected pregnant women without complications showed almost the same difference with the control group, this difference in groups Ia-IIIa was from $23.4 \%$ to $28.6 \%$. But in groups with complications (Ib-IIIb) this difference was between $67.8 \%$ and $68.1 \%$ (Fig. 1). 


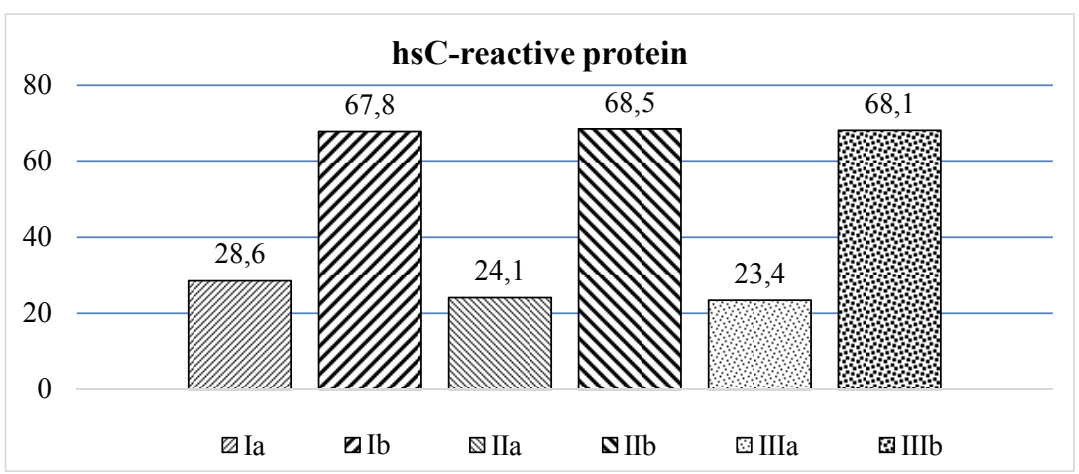

Fig. 1. Comparison content of levels of hs-CRP in groups of B19 infected pregnant women Ia-IIIa (without complications) with groups $\mathrm{Ib}-\mathrm{IIIb}$ ( with clinical complications)

\section{Discussion}

The present research of levels of hs-CRP has established a moderate increasing its concentration in the blood serum of pregnant women with parvovirus B19 infection, which is connected with slight damage of tissues. It is well-known, that hs-CRP can stimulate inflammatory response by activating of classical complement pathway, tissue damage and induction of pro-inflammatory cytokines in monocytes [10]. Those factors can cause adverse pregnancy outcomes. Current study shows, that parvovirus B19 infection during pregnancy is related with increasing of hs-CRP on all gestation periods. Significant increasing of hs-CRP level can activate phagocytes. Absorption of protein by neutrophils leads to hs-CRP proteolysys, it causes releasing of immunoactive low weight peptides that can modulate the functions of neutrophils, monocytes and macrophages (increases chemotaxis of phagocytes, production of superoxide anion and IL-1). In monocytes hs-CRP enhances the generation of active forms of oxygen and tumor necrosis factor-a. Additionally, hs-CRP affects other immune competent cells: hs-CRP can connect with T-helper cells, cytotoxic T-lymphocytes and NK-cells (also, NK-cells, can produce CRP by themselves).

It is known that CPR can exacerbate inflammatory responses through complement activation, tissue damage, and induction of inflammatory cytokines in monocytes thus lead to adverse pregnancy outcomes. Results of current study show that parvovirus infection during pregnancy is connected with increased levels of CRP on all terms of pregnancy. Significant increase in the level of CRP may provoke activation of phagocytic cells. Absorption of protein by neutrophils leads to CRP proteolysys, which results in the isolation of immunoactive low molecular weight peptides that can modulate the functions of neutrophils and monocytes/macrophages (increased chemoacusis of phagocytes, production superoxide anion and interleukin-1). In monocytes, CRP increases the generation of active forms of oxygen, factor TNF- $\alpha$. In addition, CRP affects other immunocompetent cells: it can bind T-helper cells, cytotoxic T-lymphocytes, NK-cells (also, NKcells, can produce CRP by themselves). CRP is the most sensitive and fastest indicator of tissue damage during inflammation. Pregnant women with high levels of C-reactive protein (CRP) in the blood are at high risk for preterm delivery. Increasing level of CRP is able to provoke the activation of phagocytic cells in various intensity. Free CRP is absorbed by neutrophils in large amounts and is rapidly internationalized. The result of CRP proteolysys in the phagosomes of neutrophils is the secretion of immunoactive low molecular weight peptides that can modulate the functions of neutrophils and monocytes/macrophages: enhance chemoacusis of phagocytes, their production of superoxide anion and IL-1. Monocytes not only bind CRP, but also synthesize it. In monocytes, CRP enhances the generation of active forms of oxygen, thereby increasing the ability of macrophages to synthesize TNF- $\alpha$. So, effect of CRP on monocytes has a more pro-inflammatory character than in the case of neutrophils, when the result of influence depends on the stage of inflammation and activity of neutrophils. In addition, CRP affects other immunocompetent cells: it can bind to lymphocytes (CD4 +, CD8 +), NK cells. Synthesis and secretion of CRP is regulated by cytokines: IL-6, IL-1 and TNF- $\alpha$. 
Therefore, the growth of the marker of systemic inflammation response - C-reactive protein, indicates an active participation in the launch of a complex mechanism of the development of fetal and pregnancy disorders, which was confirmed in groups of women with clinical complications in different periods of pregnancy.

\section{Conclusions}

1. An increased level of the marker of systemic inflammation hs-CRP in the blood serum testifies to its active participation in the launch of a complex mechanism for the development of labor activity and the occurrence of fetal disorders, which was confirmed in groups of pregnant women with clinical complications in different pregnancy periods.

2. Significant growth (in 1.6 and 1.5 times) of the sensible marker of systemic inflammation of C-reactive protein in infected pregnant women in the 1st and 2nd trimesters was found, the most significant in women with clinical complications of pregnancy and to the same extent (in 1.7 times) in different trimesters of pregnancy.

\section{References}

[1] Ahushkova, L.M., Bulah, N. A., Moskalenko, N. P., Sukharev, A. E., Nikolaev, A. A. (2014). Izychenie C- reactivnogo protein pri beremennosti. Fundamentalnie issledovaniya, 4 (3), 619-623.

[2] Francis, F., Bhat, V., Mondal, N., Adhisivam, B., Jacob, S., Dorairajan, G., Harish, B. N. (2017). Fetal inflammatory response syndrome (FIRS) and outcome of preterm neonates - a prospective analytical study. The Journal of Maternal-Fetal\& Neonatal Medicine, 1-5. doi: 10.1080/14767058.2017.1384458

[3] Shahshahan, Z., Rasouli, O. (2014). The use of maternal C-reactive protein in the predicting of preterm labor and tocolytic therapy in preterm labor women. Advanced Biomedical Research, 3 (1), 154. doi: $10.4103 / 2277-9175.137864$

[4] Chandrashekara, S. (2014). C-reactive protein: An inflammatory marker with specific role in physiology, pathology, and diagnosis. Internet Journal of Rheumatology and Clinical Immunology, 2. doi: $10.15305 / \mathrm{ijrci} / \mathrm{v} 2 \mathrm{is} 1 / 117$

[5] Igipova, M. B., Serduk, G. V., Momot, A. P. (2010). Kliniko-diagnosticheskoe znachenie C-reactivnogo belka kak markera sistemnogovo spalitelnogo otveta pri beremennosti (obzorliteraturu). Klinicheskaya laboratornaya diagnostika, 6, 3-8.

[6] Malek, A., Bersinger, N. A., Di Santo, S., Mueller, M. D., Sager, R., Schneider, H. et. al. (2006). C-Reactive Protein Production in Term Human Placental Tissue. Placenta, 27 (6-7), 619-625. doi: 10.1016/ j.placenta.2005.05.009

[7] Sacks, G. P., Syani, L., Lavery, S., Trew, G. (2004). Maternal C-reactive protein levels are raised at 4 weeks gestation. Human Reproduction, 19, 1025-1030. doi: 10.1093/humrep/deh179

[8] Jauniaux, E., Gulbis, B., Jamil, A., Jurkovic, D. (2015). Evaluation of the role of maternal serum high-sensitivity C-reactive protein in predicting early pregnancy failure. Reproductive BioMedicine Online, 30 (3), 268-274. doi: 10.1016/j.rbmo.2014.11.009

[9] Sharmin, S., Chy, S., Alam, D., Banu, N., Rashid, F., Kabir, S. (2017). Association of Serum C-reactive Protein in Preeclampsia and its Effect on Fetal Birth Weight - A Case Control Study. Bangladesh Journal of Obstetrics \& Gynaecology, 31 (2), 75-80. doi: 10.3329/bjog.v31i2.34214

[10] Tjoa, M. L., van Vugt, J. M. G., Go, A. T. J. J., Blankenstein, M. A., Oudejans, C. B. M., van Wijk, I. J. (2003). Elevated C-reactive protein levels during first trimester of pregnancy are indicative of preeclampsia and intrauterine growth restriction. Journal of Reproductive Immunology, 59 (1), 29-37. doi: 10.1016/s0165-0378(02)00085-2

[11] Pitiphat, W., Gillman, M. W., Joshipura, K. J., Williams, P. L., Douglass, C. W., Rich-Edwards, J. W. (2005). Plasma C-Reactive Protein in Early Pregnancy and Preterm Delivery. American Journal of Epidemiology, 162 (11), 1108-1113. doi: 10.1093/aje/kwi323

[12] Hvilsom, G., Thorsen, P., Jeune, B., Bakketeig, L. (2002). C-reactive protein: a serological marker for preterm delivery? ActaObstetriciaetGynecologicaScandinavica, 81 (5), 424-429. doi: 10.1034/j.16000412.2002.810509.x

[13] Palasanthiran, P., Starr, M., Jones, C., Giles, M. (2014). Management of perinatal infections. Sydney: Australasian Society for Infectious Diseases (ASID) Inc., 90. 
[14] Peltier, M. R., Faux, D. S., Hamblin, S. D., Silver, R. M., Esplin, M. S. (2010). Cytokine production by peripheral blood mononuclear cells of women with a history of preterm birth. Journal of Reproductive Immunology, 84 (1), 111-116. doi: 10.1016/j.jri.2009.10.002

[15] Lohsoonthorn, V., Qiu, C., Williams, M. A. (2007). Maternal serum C-reactive protein concentrations in early pregnancy and subsequent risk of preterm delivery. Clinical Biochemistry, 40 (5-6), 330-335. doi: 10.1016/j.clinbiochem.2006.11.017

[16] Nagaraj, R. S., Anand, K. P. (2017). Study of serum high sensitive C-Reactive protein and ferritin in preterm labor. International Journal of Clinical Biochemistry and Research, 4 (3), 213-215.

[17] De Jong, E. P., de Haan, T. R., Kroes, A. C. M., Beersma, M. F. C., Oepkes, D., Walther, F. J. (2006). Parvovirus B19 infection in pregnancy. Journal of Clinical Virology, 36 (1), 1-7. doi: 10.1016/j.jcv.2006.01.004

[18] Crane, J., Mundle, W., Boucoiran, I., Gagnon, R., Bujold, E., Basso, M. et. al. (2014). Parvovirus B19 Infection in Pregnancy. Journal of Obstetrics and Gynaecology Canada, 36 (12), 1107-1116. doi: 10.1016/ s1701-2163(15)30390-x

[19] Bonvicini, F., Bua, G., Gallinella, G. (2017). Parvovirus B19 infection in pregnancy - awareness and opportunities. Current Opinion in Virology, 27, 8-14. doi: 10.1016/j.coviro.2017.10.003

[20] Karabulut, A., Gok, S., Kocyigit, A. (2013). Non-immune hydrops fetalis without anemia due to parvovirus B19. International Journal of Gynecology \& Obstetrics, 124 (1), 82. doi: 10.1016/j.ijgo.2013.07.021

[21] Hvilsom, G., Thorsen, P., Jeune, B., Bakketeig, L. (2002). C-reactive protein: a serological marker for preterm delivery? Act a Obstetricia et Gynecologica Scandinavica, 81 (5), 424-429. doi: 10.1034/j.16000412.2002.810509.x

[22] Shah, J., Baxi, B. (2016). Identification of biomarkers for prediction of preterm delivery. Journal of Medical Society, 30 (1), 3-14. doi: 10.4103/0972-4958.175790

[23] Rebrova, O. Y. (2006). Statisticheskiy analiz medicinskih dannih: primenenie paketa prikladnuh program Statistica. Moscow: Mediasfera, 312.

\title{
CHANGES IN THE CELL SQUAD OF ILIAC LYMPH NODES OF WHITE RATS IN CASE OF LONGTERM INFLUENCE OF NALBUFIN
}

\author{
Olesya Valko \\ Department of Human Anatomy and Histology \\ Uzhhorod National University \\ 22 Peremohy str., Uzhhorod, Transcarpathian region, Ukraine, 88015 \\ anatomolesya@ukr.net \\ Andrew Holovatskyi \\ Department of Human Anatomy and Histology \\ Uzhhorod National University \\ 22 Peremohy str., Uzhhorod, Transcarpathian region, Ukraine, 88015 \\ holand36@ukr.net
}

\footnotetext{
Abstract

The article presents data on the change in the cellular composition of the lymph nodes of the white rats, males of reproductive age, who received intramuscular opioid analgesics - nalbuphine every day for six weeks. The weekly dose of nalbuphine was gradually increased, creating a model of physical opioid dependence according to the patent of Ukraine No. 76564 U. All experimental animals were divided into 8 groups.

Morphometric method was used to determine the relative number of cells of the lymphoid series - small, medium and large lymphocytes, blasts and plasmocytes in the cloak zone and the embryonic center of the secondary lymphoid nodes and brain strands of the lymph nodes. Morphometric studies were performed using a system of visual analysis of histological preparations.
} 